\title{
Evaluation of Nutritional, Microbial and Sensory Properties of Complementary Food Developed from Kocho, Orange-Fleshed Sweet Potato (Ipomoea Batatas L.) and Haricot Bean (Phaseolus Vulgaris) for Under Five Years Children in Boricha Woreda, South Ethiopia
}

\author{
Gezahegn Nigusse $^{1} \quad$ Tadewos Hadero $^{1} \quad$ Tarekegn Yoseph $^{2}$ \\ 1.Food Science and Postharvest Technology, College of Agriculture Hawassa University, Ethiopia) \\ 2.Horticulture and Plant Science, College of Agriculture Hawassa University, Ethiopia)
}

\begin{abstract}
In sub-Saharan African specifically in Ethiopia malnutrition is a great challenge. Protein energy malnutrition, in children associated with poor nutritional knowledge resulting in early weaning, delayed introduction of complimentary foods, low protein diet and sever or frequent infection. In Ethiopia the intake of vitamin A is inadequate, especially provision of the vitamin through dietary improvement, food fortification, and supplementation is less. The consumption of vitamin A-rich fruits and vegetables and foods made from roots and tubers about 24-25\%. Boricha Woreda was selected because of its potential for growing kocho, haricot beans, orange fleshed sweet potato (OFSP) and the exposure to food insecurity with a high number of malnourished children. The purpose of this study was to assess nutritional, microbial and sensory properties of complementary food developed from Kocho, orange fleshed sweet potato and haricot beans for under five years children. Porridge was developed with different proportion of kocho to haricot bean flour: 90:10, 80:20, 70:30 and 100:0 (control) and constant amount of OFSP (15\%). The proximate composition analyses of porridge were done by AOAC 2000. The beta carotene/Vitamin A was determined by using High Performance Liquid Chromatography (HPLC). The total mold and yeast counts and total plate count for the safety were carried out by using the standard procedure for examining of microbial load on the food products. Sensory acceptability of the porridge was evaluated with 30 panelists comprising of mother-children in pair using 5 point hedonic scale. The result of the study showed that the proximate composition (moisture content, crude protein, crude fat, and total ash) fulfills the minimum recommended daily allowance (RDA) for children aged between 6-23months. OFSP incorporated porridge were rich in Vitamin A content, and full fills $65.14 \%$ daily RSI (RDA) of vitamin A. The microbial analyses of the developed porridge were within the microbiologically accepted limit. All porridge were accepted and liked by the consumers. Thus, based on the finding of this study it was suggested that mothers/caregivers should feed their children haricot bean and OFSP incorporated porridge.
\end{abstract}

Keywords: Children, protein-energy malnutrition, VA deficiency.

DOI: $10.7176 / \mathrm{FSQM} / 85-01$

Publication date:March $31^{\text {st }} 2019$

\section{Introduction}

\subsection{Background}

High malnutrition rates in Ethiopia pose a significant burden in economic and social development (Fottrell et al., 2009). Major contributing factors to malnutrition among infants and children are poverty and low purchasing power of the family (Woldemariam and Genebo, 2002). Food-based strategies are key to addressing hunger and malnutrition, and the desired characteristics of foods include high nutrient density, low bulk property as well as utilization of low cost and locally-available crops. This will ensure early adoption at home and at the village level (Mahgoub, 1999). Despite children's high requirements for nutrients, their diets in developing countries are mostly comprised of cereals or starchy root crops, which when eaten exclusively, result in deficiencies of key nutrients such as proteins, iron, zinc, calcium, riboflavin, vitamin A, and vitamin-C (Allen, 2006). Although Ethiopia has a fairly large livestock population, availability of meat and milk for local human consumption is limited, especially in rural areas where wealth index values are in the lower quintiles according to the most recent Demographic and Health Survey.

Pulses (haricot bean) have several important attributes including high nutritional value, long storage times and relatively low cost in comparison to animal products. Haricot bean (Phaseolus vulgaris) make an important contribution in protein, energy and micronutrient provision to populations in the developing world Dilis, 2009. It is extremely diverse crops in terms of cultivation methods, uses, and the range of environments to which it has been adapted. It provide dietary protein that play essential role in human nutrition, especially in combination with low protein foods (Broughton et al., 2003). Low protein content of enset limits its product (kocho) as a food products and the consumer faces the protein energy malnutrition (Steven et al., 1997).Orange-fleshed sweet 
potato (Ipomoea batatas L.) as a staple food has an advantage over most vegetables in that it can supply significant amounts of vitamin A and energy simultaneously, thus helps to address both Vitamin-A deficiency and also under nutrition (Bouis, 2002).

Complementary foods can be prepared by mixing kocho with locally available pulse products to produce foods with adequate energy and protein levels and orange fleshed sweet potato for vitamin A. Applications of food processing techniques like germination and fermentation both minimizes anti nutritional factors and enhances nutrient intake and palatability (Egounlety, 2002). In order to overcome these nutritional problems, consideration of locally available, affordable and relevant sources of food is important. The recommendations from $\mathrm{FAO} / \mathrm{WHO} / \mathrm{UNU}$ to add a maximum of $40 \%$ legumes/protein rich foods to cereal-based complementary food for young children has been made (FAO/WHO/UNU, 1985). However, the feasibility and acceptability of this recommendation deserves testing in Ethiopia, where beans are locally grown and relatively inexpensive (compared to meat). For example, only $20 \%$ of young children eat complementary foods prepared from legumes, with most consuming kocho-based foods but little or without animal foods (CSA, 2012). Thus, the purpose of this study was used to develop and test acceptability, safety and nutrient content of kocho-based complementary food blended with haricot beans and orange fleshed sweet potato which are widely available but not wellconsumed for under five years children, especially in the study area.

\subsection{Objective}

1.2.1 General objective

General objective of the study is to assess nutritional, microbial and sensory properties of complementary food developed from kocho, orange fleshed sweet potato and haricot beans for under five years children.

1.2.2. Specific objectives

2. To prepare complimentary food from kocho, haricot bean and OFSP flour with different blending ratio.

3. To assess microbial load and safety of developed complimentary foods at storage.

4. To determine proximate composition of developed complimentary food.

5. To determine vitamin A content of developed complimentary food.

6. To assess the sensory acceptability of developed complimentary foods by mother and their children.

\section{Materials and Method}

\subsection{Description of the study area}

The study was conducted in Boricha Woreda; Sidama Zone, South Nations, Nationalities and Peoples Regional State, is located at $311 \mathrm{~km}$ South of Addis Ababa. Boricha has an estimated area of $588.05 \mathrm{sq} \mathrm{km}$. Administratively the Woreda comprises 39 Kebeles of which 3 Kebeles are semi-urban and the others are rural. Based on the information from Boricha woreda finance and economy office the Woreda has estimated total populations of 301,312 of these 151,008 are men and 150,304 are women and 95.6 percent of the populations were estimated to be rural inhabitants (CSA, 2013). The major source of income in the Woreda is crop production, livestock rearing, petty trade, labor and carpentry. The major crops grown in the area were maize, enset, sorghum, haricot beans, yams, taro and sweet potatoes and fruits (including avocado and pineapple).

\subsection{Sample collection and preparation}

Kocho, orange fleshed sweet potato and haricot beans were collected from Boricha woreda. Samples were taken randomly from upper, middle and lower side of sacks/jute. Sample preparation was done in Hawassa University, School of Nutrition, Food Science and Technology Laboratory. All raw materials obtained from Boricha woreda and ingredients obtained from the local market brought in $50 \mathrm{~kg}$ lots. Kocho was squeezed, sun dried, crumbled and passed through a household sieve to reduce fiber. Haricot beans was washed and soaked in clean tap water for 12 hours. After draining, the haricot beans were germinated at room temperature for 24 hours, rinsed, dried in the sun and roasted using an oven to further reduce anti-nutritive factors and improve the flavor of the final product. Processing was done as of Ghavidel and Prakash Ghavidel and Prakash, 2007by slight modification. The roasted haricot beans were milled into flour. Orange fleshed sweet potato was prepared by selecting healthy one, washing in clean water, peeling, slicing, soaking in salt solution $(1 \% \mathrm{NaCl} / 30$ minute, drying in solar dryer, milling to flour, and sieved (Hagenimana et al., 1999).

\subsection{Formulation and development of complimentary food}

Different kocho, orange fleshed sweet potato and haricot bean flours were blended in the ratios shown in Table 1 below to investigate their effects on the proximate, microbial and sensory quality of porridge. Then the complimentary porridge was prepared by using $100 \mathrm{~g}$ of the mixtures and added to $300 \mathrm{ml}$ of boiling water and cooked for 15 minutes. 
Table 1. Blending ratio of kocho, haricot bean and OFSP

\begin{tabular}{llll}
\hline Blend proportion & Koch flour (\%) & Haricot bean flour (\%) & OFSP flour (\%) \\
\hline C & 100 (control) & 0 & 15 \\
T1 & 90 & 10 & 15 \\
T2 & 80 & 20 & 15 \\
T3 & 70 & 30 & 15 \\
\hline
\end{tabular}

\subsection{Proximate composition determination}

The proximate composition (moisture content, crude protein, crude fat, crude fiber and total ash) analyses of porridge were done in duplicates by using the methods described by AOAC (2000). Besides, carbohydrate content, calorie value, and beta carotene were determined by the methods developed by Mathew (2006), FAO/WHO (2005), and Rodriguez, (1997), respectively.

\subsection{Microbial analysis}

The total mold, yeast and bacteria count were carried out on the porridge samples using the procedures developed by Olaoye et al. (2007) with slight modification.

\subsection{Sensory evaluation of porridge}

Sensory quality in terms of color, taste appearance, flavor, texture and over all acceptability of the porridge samples were evaluated in triplicate by 30 consumer based panelists using 5 point hedonic scale according to Olaoye et al. (2007) with slight modification.

\subsection{Data Management and Analysis}

Completely Randomized design (CRD) was used to investigate the effect of the different blending ratios on the nutritional composition and microbial load but Randomized complete block design (RCBD) was used for sensory analysis. Data analysis was carried out using one way analysis of variance (ANOVA) taking blending ratio as independent variables and the parameters (proximate, vitamin A, sensory and microbial) as dependent variables. When ANOVA produces significant difference at $\mathrm{P}<0.05$, the means of each parameter was compared using the Fischer's least significant differences (LSD) procedures. The analysis was carried out by using Statistical Analysis System (SAS for windows; SAS 9. 1 software version, Institute, Inc. Cary, NC, USA).

\section{Results and Discussion}

\subsection{Effects of blending proportion on proximate composition of developed porridge}

As shown on Table 2 , there was a significant $(p<0.05)$ difference in the proximate composition of developed porridge. With an increase in the haricot bean flour proportion from $10-30 \%$ in the porridge, there was a decrease in the moisture content, crude fiber and total carbohydrate, whereas the amount of crude fat, crude protein, total ash increased. Gross energy of the product was irregularly increased with increasing the proportion of haricot bean in the formulation.

Table 2. Effects of blending proportion on proximate composition of developed porridge

\begin{tabular}{lllllllll}
\hline $\begin{array}{l}\text { Kocho: } \\
\text { Haricot } \\
\text { bean }\end{array}$ & Moisture & $\begin{array}{l}\text { Crude } \\
(\%)\end{array}$ & $\begin{array}{l}\text { Crude } \\
\text { protein (\%) }\end{array}$ & Ash (\%) & $\begin{array}{l}\text { Crude } \\
\text { fiber (\%) }\end{array}$ & Total CHO & $\begin{array}{l}\text { Energy } \\
\text { (Kcal/100g) }\end{array}$ \\
\hline $\mathrm{C}(100: 00)$ & $7.84 \pm 0.01^{\mathrm{a}}$ & $8.43 \pm 0.01^{\mathrm{d}}$ & $2.85 \pm 0.01^{\mathrm{d}}$ & $1.99 \pm$ & $4.76 \pm 0.01^{\mathrm{a}}$ & $78.89 \pm 0.00^{\mathrm{a}}$ & $402.83 \pm 0.01^{\mathrm{c}}$ \\
& & & & $0.00^{\mathrm{d}}$ & & & & \\
$\mathrm{T} 1(90: 10)$ & $6.92 \pm 0.01^{\mathrm{b}}$ & $9.12 \pm 0.00^{\mathrm{c}}$ & $7.24 \pm 0.00^{\mathrm{c}}$ & $2.98 \pm 0.01^{\mathrm{c}}$ & $3.04 \pm 0.01^{\mathrm{b}}$ & $71.74 \pm 0.00^{\mathrm{b}}$ & $398 \pm 0.01^{\mathrm{d}}$ \\
$\mathrm{T} 2(80: 20)$ & $6.33 \pm 0.01^{\mathrm{c}}$ & $11.64 \pm 0.15^{\mathrm{b}}$ & $9.56 \pm 0.01^{\mathrm{b}}$ & $3.46 \pm 0.05^{\mathrm{b}}$ & $2.56 \pm 0.01^{\mathrm{c}}$ & $69.01 \pm 0.00^{\mathrm{c}}$ & $419.04 \pm 0.02^{\mathrm{b}}$ \\
$\mathrm{T} 3(70: 30)$ & $5.73 \pm 0.01^{\mathrm{d}}$ & $12.02 \pm 0.07^{\mathrm{a}}$ & $11.99 \pm 0.01^{\mathrm{a}}$ & $3.88 \pm 0.02^{\mathrm{a}}$ & $2.98 \pm 0.00^{\mathrm{d}}$ & $66.38 \pm 0.00^{\mathrm{d}}$ & $412.56 \pm 0.02^{\mathrm{a}}$ \\
\hline
\end{tabular}

Values are means \pm standard deviation. Means with different letters across the column are significantly different at $95 \%$ Confidence Interval $(\mathrm{P}<0.05)$. All values are average of duplicates.

The moisture contents of porridge obtained in this study were 5.73 to 7.84 , which is in agreement with the values obtained from Shimelis and Rakshit (2005) that is within the range of 5.76-7.84. It was also in agreement with the maximum limit specification of moisture content of porridge determined by World Health Organization is $10 \%$. Thus, the shelf life of the composite flour might be elongated due to less moisture content and water activity, which not make the product easily susceptible to microbial spoilage.

The haricot bean content in the product positively affected the crude fat content, i.e., fat value increased. This could be due to the high amount of fat in haricot bean flour. Lalude and Fashakin (2006) reported that the fat content of weaning food from sorghum and oil-seeds is $9.87 \%$ but this value is higher than the current finding but legumes have higher fat content compared kocho.

To increase the quality of protein in complementary foods, mixing kocho and haricot bean is important in 
developing countries. Protein content $(2.85 \%)$ of control sample was significantly less than the treated samples T1 (7.24\%), T2 $(9.56 \%)$, and T3 (11.99\%) protein content. This might be due to amount of protein content haricot bean. Which satisfies the standard made to cereal based porridges by MOH (2006). The finding of this study was above the minimum (6.3\%) suggested by Reeds and Garlick (2007) and between the range of 11-13\% reported by Walker (2009). The required amount of protein intake, 20g/day RDA for children aged between 6-23 months, depending on the amount of breast milk consumed but it is difficult to obtain this amount per day. In our study the amount of protein that contains $30 \%$ soybean blended porridge fulfill $(59.95 \%)$ of the RDA for children aged between 6-23months. Incorporating 30\% haricot bean flour to kocho increased the amount of protein content in porridge the diet of children, which partially fulfills the recommended dietary allowance for daily intake of protein for children's.

The higher value of ash content was recorded for T3 $(3.88 \mathrm{~g} / 100 \mathrm{~g})$ in a porridge formulated from $30 \%$ haricot bean and 70\% kocho. This implies that the haricot bean total ash is higher than control sample of kocho $(1.99 \mathrm{~g} / 100 \mathrm{~g})$. This might be due to as the result of the total ash found in haricot bean, this is the indicator of the minerals in food products.

The added amount of haricot bean during formulation of porridge negatively affects the amount of crude fiber in the porridges, i.e., increase in haricot bean proportion decreased the fiber content of the product. This might due to the presence of higher fiber content in kocho but the whole samples were at food grade level for crude fiber content. This is in agreement with the standard for the complementary food, which not exceed $5 \mathrm{~g} / 100 \mathrm{~g}$ dry matter (Haidar, 2011).

The carbohydrate was found to be within the range of $66.38-71.74 \%$ for the $10-30 \%$ haricot been incorporated porridge and $78.89 \%$ for the control. When the amount of haricot bean increases, the amount of carbohydrate decreases in the kocho-haricot bean porridge, this might be due to the presence of high carbohydrate content in kocho flour. Children better to consume complementary foods of semisolid consistency with adequate energy and nutrient densities to supplement breast milk. Breast milk alone is no longer sufficient to meet the nutritional requirement of the children from 6 month onward Rickman et al., 2007. The calculated energy values of the porridges of the present study ranges from $(398 \mathrm{kcal} / 100 \mathrm{~g}$ to $412 \mathrm{kcal} / 100 \mathrm{~g})$ were found to be above the minimum recommended level. This could be due to the higher energy value found in kocho. The minimum desirable level of energy that complementary foods should provide was suggested to be $370 \mathrm{kcal} / 100 \mathrm{~g}$ (Walker, 2009).

\subsection{Effects of blending proportion on vitamin A contribution for RDA of children}

Many new products development trials focus on improving the protein and energy density of baby foods. However, new product development has to get attention on Vitamin A Deficiency alleviating foods for children's. VAD in children's is around 37.7\% (Mohammad et al., 2003) which also shows that the area require serious attention on new food product development. OFSP is easy crop to cultivate in farmer's field, nutritional, drought resistant, high yield and shorter harvesting period. Hence children, which are the most vulnerable group of the rural communities to VAD, primarily benefited from OFSP flour based product such as porridge. Incorporation of OFSP (15\%) improved the vitamin A content $(260.58 \mu \mathrm{g} / 100 \mathrm{~g})$ of porridge compared to that of the control ( $0 \%$ VA content). According to FAO/WHO FAO/WHO (2005) recommendation RDA of VA (recommended safe intake (RSI) for children's are $400-450 \mu \mathrm{g} /$ day. So if children eat around $15 \%$ OFSP incorporated porridge daily, they can get $65.14 \%$ daily RSI (RDA) of vitamin A. Therefore, growing OFSP as a home garden crop is practical food based approach to alleviate VAD in the community, which is easily acceptable by children's because of its sweet taste, as a result this helps to alleviate VAD.

3.3 Effects of blending proportion on microbial load of porridge

Table 3. Microbial Load $(\log 10 \mathrm{cfu} / \mathrm{g})$ on porridge

\begin{tabular}{lll}
\hline Koch: Haricot Bean & Total plate count & Mold and Yeast count \\
\hline $100: 00$ & $0.62 \pm 0.05^{\mathrm{a}}$ & $1.12 \pm 0.00^{\mathrm{a}}$ \\
$90: 10$ & $0.61 \pm 0.06^{\mathrm{a}}$ & $1.04 \pm 0.10^{\mathrm{a}}$ \\
$80: 20$ & $0.63 \pm 0.06^{\mathrm{a}}$ & $1.03 \pm 0.05^{\mathrm{a}}$ \\
$70: 30$ & $0.60 \pm 0.00^{\mathrm{a}}$ & $1.13 \pm 0.04^{\mathrm{a}}$ \\
\hline
\end{tabular}

Values are means \pm standard deviation. The means with the same letters across the column are not significantly different at $95 \%$ Confidence Interval $(\mathrm{P}<0.05)$. All values are average of duplicates.

The microbial load (total plate, mold and yeast count) on the porridge indicated in terms of $\log \mathrm{cfu} / \mathrm{g}$ presented in Table 3 . There were no statistically significant differences in microbial load on entire samples made of kocho and haricot bean at different proportions with constant proportion of OFSP. However, total plate count ranges from 0.60 to $0.63 \log 10 \mathrm{cfu} / \mathrm{g}$, whereas mold and yeast count ranges from 1.03 to $1.13 \log 10 \mathrm{CFU} / \mathrm{g}$. The finding of this study was in agreement with finding of Mohammad et al. (2003). The lower count of microbial load of this study might be due to the soaking with salt solution, and cooking killed some of the heat sensitive 
micro-organisms in the production of porridge (Agu et al., 2008). The International commission for microbiological specification for foods, states that ready-to-eat foods with plate count between $0-10^{3} \mathrm{cfu} / \mathrm{g}$ are acceptable, between $10^{4}$ and $10^{5} \mathrm{cfu} / \mathrm{g}$ is tolerable and $10^{6} \mathrm{cfu} / \mathrm{g}$ and above is unacceptable (Daniyan and Nwokwu, 2011). For foods the number of yeasts and fungi must not exceed $10^{2} \mathrm{cfu} / \mathrm{g}$ (Delia and Corina, 2005). Thus, the finding of the present study was within the acceptable limit and therefore, the product is microbiologically safe.

\subsection{Effects of blending proportion on sensory acceptability}

Table 4 shows the sensory acceptability test of the porridge. There were no differences in sensory acceptability of porridge blended with different proportion of kocho, haricot bean and orange fleshed sweet potato flour. Sensory evaluation in the present study was done with mothers and their children's at age below two years. All the products, i.e., control sample and whole treated samples were organoleptically accepted. According to the finding of Ebunoluwa et al. (2017) the acceptability of complimentary food developed by the blends of orange flesh sweet potato, sorghum, and soybean with the maximum amount of the blending ration up to $30 \%$ was equally accepted with the control product. Sensory quality of formulated complementary food corresponding to food choice of infants is important apart from nutrient and sufficient energy density (Muhimbula et al., 2011). Vasantharuba et al. (2012) also reported that substitutions of $30 \%$ of wheat flour by sweet potato flour were feasible and acceptable for baked products. Consumer tests in a market in Mozambique showed a strong preference for golden bread made with boiled and mashed sweet potato 38\% of weight of wheat flour (Graham et al., 2009). Even though most of these researches agree on the above sweet potato flour substitution proportion and Omosa (1997) recommended that the levels of substitution are higher for non-sweet products and lower for sweet products in order to increase the acceptability by consumers.

Table 4. Sensory acceptability test of mothers/caregivers $(\mathrm{N}=30)$

\begin{tabular}{|c|c|c|c|c|c|c|c|}
\hline $\begin{array}{l}\text { Kocho: } \\
\text { bean }\end{array}$ & Haricot & Color & Appearance & Flavor & Taste & Mouth feel & $\begin{array}{l}\text { Overall } \\
\text { acceptability }\end{array}$ \\
\hline 100:00 & & $4.51 \pm 0.49^{\mathrm{a}}$ & $4.53 \pm 0.48^{\mathrm{a}}$ & $4.69 \pm 0.41^{\mathrm{a}}$ & $4.62 \pm 0.49^{\mathrm{a}}$ & $4.68 \pm 0.41^{\mathrm{a}}$ & $4.65 \pm 0.48^{a}$ \\
\hline 90: 10 & & $4.48 \pm 0.56^{\mathrm{a}}$ & $4.51 \pm 0.50^{\mathrm{a}}$ & $4.61 \pm 0.46^{\mathrm{a}}$ & $4.59 \pm 0.56^{\mathrm{a}}$ & $4.60 \pm 0.46^{\mathrm{a}}$ & $4.61 \pm 0.56^{\mathrm{a}}$ \\
\hline 80: 20 & & $4.53 \pm 0.62^{\mathrm{a}}$ & $4.63 \pm 0.49^{\mathrm{a}}$ & $4.77 \pm 0.42^{\mathrm{a}}$ & $4.54 \pm 0.62^{\mathrm{a}}$ & $4.70 \pm 0.42^{\mathrm{a}}$ & $4.56 \pm 0.56^{\mathrm{a}}$ \\
\hline $70: 30$ & & $4.62 \pm 0.52^{\mathrm{a}}$ & $4.60 \pm 0.62^{\mathrm{a}}$ & $4.64 \pm 0.51^{\mathrm{a}}$ & $4.61 \pm 0.52^{\mathrm{a}}$ & $4.68 \pm 0.51^{\mathrm{a}}$ & $4.63 \pm 0.51^{\mathrm{a}}$ \\
\hline
\end{tabular}

Values are means \pm standard deviation. The means with the same letters across the column are not significantly different at $95 \%$ Confidence Interval $(\mathrm{P}<0.05)$. All values are average of duplicates.

\section{Conclusion and Recommendations}

\subsection{Conclusion}

All porridge developed from kocho and haricot bean flour in different proportion and constant amount of OFSP $(15 \%)$ were improved some proximate compositions such as crude fat, crude protein, and total ash, whereas decreased moisture content, crude fiber and total carbohydrate. The new product developed for children's were microbiologically safe and organoleptically accepted. The porridge can serves as a vehicle for delivering protein and VA through food based approach to the children in the study area, these products are nutritionally, microbiologically as well as sensorial quality and fulfill the children's requirements.

\subsection{Recommendations}

Based on the study result, the following recommendation is derived.

Food based approaches require a multi-sectorial collaborative work. Thus, Woreda agricultural officials, health officials, and education in the study area and Hawassa university work together to promote protein and VA rich haricot bean and OFSP incorporated kocho based porridge to the mothers/caregivers of children to feed their children to prevent protein energy malnutrition and VAD problem of children in the study area.

\section{Acknowledgements}

We would like to thank Hawassa University, Research Directorate for funding for this study.

\section{References}

A. F. Walker, The contribution of weaning foods to protein-energy malnutrition, Nutrition Research Review, 3 , 2009, 25-47.

A. Steven, Brandt, Anita Spring, Clifton Hiebsch, J. Terrence McCabe, Endale Tabogie, Mulugeta Diro, Gizachew Wolde-Michael, Gebre Yntiso, Masayoshi Shigeta, and Shiferaw Tesfaye, The "tree against hunger" enset-based agricultural systems in Ethiopia American association for the advancement of science with Awassa Agricultural Research Center Kyoto University Center for African Area Studies and University of Florida, 1997. 
Agu. A. N. Anosike, and I.A. Jideani, Physicochemical and microbial qualities of dambu produced from different cereal grains. Pakistan Journal of Nutrition 7 (1), 2008, 21-26.

AOAC (Association of Official Analytical Chemists), Official Method of Analysis, $16^{\text {th }}$ ed. Washington, DC, 2000, 491-494.

CSA (Central Statistical Agency Ethiopia) and ICF International, Ethiopian demographic and health survey 2011, Addis Ababa, Ethiopia and Calverton, Maryland, USA. Central Statistical Agency and ICF International, 2012.

CSA (Central Statistical Agency), Population projection of Ethiopia for all Regions at Wereda level from 20142017, Addis Ababa Ethiopia, 2013, 61-79.

Delia Viosencu, and Corina Mişcă, The microbiological parameters' in technological process of bread production, Scientific Researches Agro-alimentary Processes and Technologies Volume XI, No. 2, 2005, 475-480.

E. Fottrell, F. Enquselassie, and P, Byass, The distribution and effect of child mortality risk factors in Ethiopia: a comparison of estimates from DSS and DHS, Ethiopian Journal of Health Develop, 23, 2009, 163-168.

Ebunoluwa Kehinde Alawode, M. A. Idowu1, A. A. Adeola, E. K. Oke1, and S. A. Omoniyi, Some quality attributes of complementary food produced from flour blends of orange flesh sweet potato, sorghum, and soybean, Croat. Journal of Food Science and Technology, 9 (2), 2017, 122 - 129.

$\mathrm{FAO} / \mathrm{WHO}$, Preparation and use of food based dietary guidelines. Report of a joint FAO/WHO consultation,(www.fao.org/documents/show_cdr.asp?url_file_/docrep/x0243e/ x0243e00.htm), 2005.

FAO/WHO/UNU, Energy and Protein Requirements. Report of a Joint FAO/WHO/UNU expert consultation, Tech. Rept. Ser. No. 724, World Health Organization: Geneva, Switzerland, 1985.

Woldemariam, G., and Genebo, T. (2002). Determinants of nutritional status of women and children in Ethiopia. Calverton, Maryland, USA.

Graham Thiele, John Lynam, Berga Lemaga, and Jan Low. (2009). Sweet potato value chains, CIP, Challenge Theme Paper 4: social sciences working paper.

Bouis, H. (2002). A new tool for fighting micronutrient malnutrition. Journal of Nutrition. 2002, 132.

Haidar, J. (2011). Common micronutrient deficiencies among food aid beneficiaries: Evidence from refugees in Ethiopia, Ethiopia. Journal of Health Development. 25(3), 222-229.

Lalude, L. O., and Fashakin, J.B. (2006). Development and nutritional assessment of a weaning food from sorghum and oil - seeds. Pakistan Journal of Nutrition. 5 (3), 257-260.

Allen, L.H. (2006). Causes of Nutrition Related Public Health Problems of Preschool Children. Journal Pediat Gastroenterology Nutrition. 2006, 8-12.

Egounlety, M. (2002). Production of legume-fortified weaning foods. Food Research International. 35, 33-237.

Omosa, M. (1997). Current and potential demand for fresh and processed sweet potato products in Nairobi and Kisumu, Kenya, International potato center (CIP), 88 Working paper (CIP) 1997-1.

Mathew George, Singhvi, Ashok, K. and Karanth, V. (2006). Rama, Luminescence chronometry and geomorphic evidence of active fold.

MOH (Ministry of Health). (2006). Complementary feeding recipe for Ethiopian children 6-23 Month old, A practical cooking and feeding guide, Ethiopia. Ministry of Health, Addis Ababa, Ethiopia. 61p.

Mohammad Ayub, Said Wahab, and Yssen Durrani (2003). Effect of water activity (Aw) moisture content and total microbial count on the overall quality of bread. International Journal of Agriculture and Biology. 3, 274-278.

Olaoye, O.A. Onilude, A. A., and Oladoye, C.O. (2007). Breadfruit flour in biscuit making: Effects on Product Quality. African Journal of Food Science. 2007, 020-023.

Reeds, P.J., and Garlick, P.J. (2007). Protein and amino acid requirement and the composition of complementary food. Journal of Nutrition. 2007, 953S-2962S.

Ghavidel, R.A., and Prakash, J. (2007). The impact of germination and de hulling on nutrients, anti-nutrients, in vitro iron and calcium bioavailability and in vitro starch digestibility of some legume seeds. LWT: 40, 12921299.

Rickman Joy, Christine, C., Bruhn, M., and Diane Barrett, M. (2007). Nutritional comparison of fresh, frozen, and canned fruits and vegetables II Vitamin A and carotenoids, vitamin E, minerals and fiber. Journal of Science Food Agriculture. 87, 1185-1196.

Rodriguez Amaya, D.B. (1997). Carotenoids and food preparation: the retention of pro-vitamin A carotenoids in prepared, processed and stored foods. USAID. OMNI Project, 1997.

Mahgoub, S.E.O. (1999). Production and evaluation of weaning foods based on sorghum and legumes. Plant Foods for Human Nutrition. 54, 29-42.

Muhimbula, S.H., Issa-Zacharia, A. and Kinab, J. (2011). Formulation and sensory evaluation of complementary foods from local, cheap and readily available cereals and legumes in Iringa, Tanzania. African Journal of Food Science. 5 (1), 26-31. 
Daniyan, S.Y., and Nwokwu, O.E. (2011). Enumeration of microorganisms associated with the different stages of bread production in futmin bakery Nigeria. International Research Journal of Pharmacy. 2011, 88-91.

Shimelis, and Rakshit, S.K. (2005). Proximate composition and physico- chemical properties of improved dry bean (Phaseolus Vulgaris L.) varieties grown in Ethiopia. Journal of Food Science and Technology. 38, 331-338.

Hagenimana, V., Carey, E. E., Gichuki, S. T., Oyunga, M. A., and Imungi, J. K. (1999). Carotenoid contents in fresh dried and processed sweet potato products. Ecology of Food and Nutrition. 37, 455-473.

Dilis, V.A. (2009). Trichopoulou Nutritional and health properties of pulses. Mediterranean Journal Nutrition Metabolism. 1, 149-157.

Vasantharuba Seevaratnam, Banumathi, P., Premalatha, M.R., Sundaram, S.P., and Arumugam, T. (2012). Studies on the preparation of biscuits incorporated with potato flour. World Journal of Dairy and Food Sciences 7 (1), 79-84.

Broughton, W.J., Hernandeze, G., Blair, M., Beebe, S., Gepts, P., and Vanderleyden, J. (2003). Beans are model food legumes. Plant and soil, 2003, 55-128. 